\title{
Proteomic and metabolomic responses of clam Ruditapes philippinarum to arsenic exposure under different salinities
}

\author{
Huifeng $\mathrm{Wu}^{\mathrm{a}, *}$, Xiaoli Liu ${ }^{\mathrm{a}, \mathrm{b}}$, Xingyan Zhang ${ }^{\mathrm{a}, \mathrm{b}}$, Chenglong $\mathrm{Ji}^{\mathrm{a}, \mathrm{b}}$, Jianmin Zhao ${ }^{\mathrm{a}}$, \\ Junbao $\mathrm{Yu}^{\mathrm{a}}$
}

a Key Laboratory of Coastal Zone Environmental Processes, Yantai Institute of Coastal Zone Research (YIC), Chinese Academy of Sciences (CAS), Shandong Provincial Key Laboratory of Coastal Zone Environmental Processes, YICCAS, Yantai, 264003, PR China

${ }^{\mathrm{b}}$ The Graduate School of Chinese Academy of Sciences, Beijing 100049, PR China

\section{A R T I C L E I N F O}

\section{Article history:}

Received 23 November 2012

Received in revised form 4 March 2013

Accepted 31 March 2013

\section{Keywords:}

Toxicological effect

Salinity

Arsenic

Ruditapes philippinarum

Proteomics

Metabolomics

\begin{abstract}
A B S T R A C T
Arsenic (As) contamination is a severe problem in the intertidal zones of the Bohai Sea (China) with wide salinity variation. In the present study, we combined proteomics and metabolomics to characterize the differential responses of arsenic in clam Ruditapes philippinarum under different salinities (31.1, 23.3 and $15.6 \mathrm{psu}$ ). Both proteomic and metabolomic responses indicated that varying salinities could significantly affect the toxicological responses of clams to As. Metabolic biomarkers revealed that the environmentally relevant arsenic $\left(20 \mu \mathrm{g} \mathrm{L}^{-1}\right)$ exposure induced disturbance in energy metabolism and/or osmotic regulation under different salinities, whereas protein biomarkers indicated oxidative stress, cellular injury and apoptosis and disturbance in energy metabolism. In addition, the up-regulated proteins including ATP synthase, succinyl-CoA synthetase and nucleoside diphosphate kinase were validated by related metabolites, succinate and ATP, which confirmed the disturbance in energy metabolism in clam gills at low salinity (15.6 psu). These findings provide important insights into toxicological effects of environmental contaminant at molecular levels using combined proteomics and metabolomics.
\end{abstract}

(c) 2013 Elsevier B.V. All rights reserved.

\section{Introduction}

Arsenic (As) is a toxic element that is released into estuarine and coastal environments from natural sources such as volcanic activity, and anthropogenic activities including mining, smelting, application of fertilizers and pesticides (Zhou et al., 2011; Baig and Kazi, 2012). In China, arsenic with an average amount of 5081 tons/year was discharged to estuarine and coastal environments due to industrial and agricultural developments from 2007 to 2010 (BCMEQ 2007-2010). Inorganic arsenic has been classified as a human carcinogen by International Agency for Research on Cancer (ATSDR, 2007). In aquatic environment, arsenic may occur in both inorganic forms, arsenite (As(III)) and arsenate (As(V)), and organic forms such as arsenoribosides, arsenobetaine, monomethylarsonic acid and dimethylarsinic acid (Harrington et al., 1997). The background levels of arsenic in open ocean seawater are typically low (1-2 $\mu \mathrm{g} \mathrm{L}^{-1}$ ) (Neff, 1997). In some heavily polluted sites along the Bohai Bay, however, the concentration of total arsenic in seawater has been up to $400 \mu \mathrm{gL}^{-1}$ (Meng et al., 2004). In addition, our recent study has demonstrated that the average content of total arsenic is $17 \mathrm{mg} \mathrm{kg}^{-1}$ dry weight in mussel Mytilus

\footnotetext{
* Corresponding author. Tel.: +86 535 2109190; fax: +86535 2109000.

E-mail address: hfwu@yic.ac.cn (H. Wu).
}

galloprovincialis along the Bohai coast. It is approximately 17 times higher than the national criteria of marine seafood safety for arsenic $\left(1 \mathrm{mg} \mathrm{kg}^{-1}\right)$. Arsenate $(\mathrm{As}(\mathrm{V}))$ is usually the dominant form of inorganic arsenic in marine ecosystems (Suhendrayatna et al., 2002). Marine organisms such as algae, bivalves and fishes can readily accumulate arsenic that exerts different toxicological effects on them (Ventura-Lima et al., 2011). Salinity changes gradually from estuaries to marine environments. Clowes and Francesconi (2004) reported that marine mussel Mytilus edulis could use a higher level of the bio-transformed speciation of arsenic, arsenobetaine, as an osmolyte in a higher salinity. However, there is a lack of studies on the toxicological effects of arsenic under different salinities at molecular levels.

With the development of modern analytical techniques, the "-omic" approaches, including genomics, transcriptomics, proteomics and metabolomics, have been well-established and successfully applied in environmental toxicology (Fedorenkova et al., 2010; Santos et al., 2010). Among these approaches, proteomics based on the combination of two-dimensional electrophoresis (2-DE) and MS remains widely useful to present complex biologically functional protein networks (Choi et al., 2012). Not only is proteomics a powerful tool for describing complete proteomes at organelle, cell, organ or tissue levels, but it can also be used to compare proteomes under environmental contaminant stress (Ahsan et al., 2009). Metabolomics is the study on a 
global profile of the low molecular weight ( $<1000 \mathrm{Da})$ metabolites which are the end products of metabolisms in various biological systems (Lindon et al., 1999; Davis, 2005). The profiling of metabolomes can present information of metabolic status in an organism to assess the biological responses induced by exogenous factors (Wu et al., 2005; Pedras and Zheng, 2010). Since metabolomics and proteomics can directly characterize the perturbations of metabolic pathways and corresponding enzymes and stress-responsive proteins, both metabolomics and proteomics have represented their practicability to elucidate the toxicological mechanisms of contaminant actions in organisms (Poynton et al., 2011; Zhang et al., 2012a,b). Especially, a combination of proteomics and metabolomics could validate and complement one another, when testing the toxicological effects of environmental pollutants (Zhang et al., 2011a,b).

To our knowledge, most investigations on the toxicological effects of arsenic have focused on fishes which are vulnerable to arsenic exposure (Liao et al., 2003; Zhang et al., 2011a,b). Manila clam (Ruditapes philippinarum) resides in both low intertidal and subtidal zones where the salinities are drastically changeable. Due to its wide geographic distribution and high tolerance to environmental changes (e.g., salinity, temperature), $R$. philippinarum is frequently used as a bioindicator in marine environmental monitoring and toxicology (Moraga et al., 2002; Liu et al., 2011).

Changeable environmental factors, such as seawater salinity and temperature, can affect the physiological status of animals, which could potentially influence the toxicological effects of contaminants in experimental animals (Laing and Child, 1996; Hines et al., 2007). In the present study, $R$. philippinarum, which can survive under the salinity ranging from 7.5 to 40.0 psu, was employed as the experimental animal to investigate the differential toxicological effects of environmentally relevant arsenic concentration under different salinities using an integrated proteomic and metabolomic approach.

\section{Materials and methods}

\subsection{Clam exposure}

A total of 120 adult clams $R$. philippinarum (shell length: $3.4-3.8 \mathrm{~cm}$ ) were purchased from a local culturing farm. After transport to the laboratory, the animals were kept for $1 \mathrm{~d}$ in natural seawater (salinity $31.1 \mathrm{psu}$ ) collected from pristine environment. Then, the clams were acclimatized at normal (31.1 psu), 75\% (23.3 psu) and 50\% (15.6 psu) salinities of seawater (prepared from different ratios of seawater and de-ionized water). The salinities were reduced gradually over a period of $3 \mathrm{~d}$ to achieve the experimental salinities which were accurately measured daily. Clams were then acclimatized at each specific salinity level for another 3 days, with daily water change. Six treatments were designed including three salinity control groups (31.1, 23.3 and $15.6 \mathrm{psu})$ and three arsenic exposure groups under corresponding salinities. The nominal concentration of arsenic was $20 \mu \mathrm{g} \mathrm{L}^{-1}$ (prepared from $\mathrm{Na}_{2} \mathrm{HAsO}_{4}$, with a stock solution concentration $200 \mathrm{mg} \mathrm{L}^{-1}$ ) that is environmentally realistic in the heavily polluted sites along the Bohai coast (Meng et al., 2004; Zhang, 2001). In each treatment, twenty clams were maintained in a tank containing $20 \mathrm{~L}$ seawater. During the acclimation and exposure periods, clams were kept at $22^{\circ} \mathrm{C}$ under a photoperiod of L12:D12, and fed daily with the Chlorella vulgaris Beij at a ration of $2 \%$ tissue dry weight. Twelve individual clams in each group were randomly selected and immediately dissected for gill tissues after exposure of $\mathrm{As}(\mathrm{V})$ for $48 \mathrm{~h}$. These gill samples were flash frozen in liquid nitrogen, and then stored at $-80^{\circ} \mathrm{C}$ before metabolite and protein determinations.

\subsection{Metabolite extraction}

Polar metabolites in the gill tissues of clams were extracted by the modified extraction protocol as described previously (Lin et al., 2007; Wu et al., 2008). Briefly, the gill tissue (ca. $100 \mathrm{mg}$ wet weight) was homogenized and extracted in $4 \mathrm{mLg}^{-1}$ of methanol, $5.25 \mathrm{mLg}^{-1}$ of water and $2 \mathrm{mLg}^{-1}$ of chloroform. The methanol/water layer with polar metabolites was transferred to a glass vial and dried in a centrifugal concentrator. The extracts were subsequently re-suspended in $600 \mu \mathrm{L}$ phosphate buffer $(100 \mathrm{mM}$ $\mathrm{Na}_{2} \mathrm{HPO}_{4}$ and $\mathrm{NaH}_{2} \mathrm{PO}_{4}$, including $0.5 \mathrm{mM}$ TSP, $\mathrm{pH} 7.0$ ) in $\mathrm{D}_{2} \mathrm{O}$. The mixture was vortexed and then centrifuged at $3000 \times \mathrm{g}$ for $5 \mathrm{~min}$ at $4{ }^{\circ} \mathrm{C}$. The supernatant substance $(550 \mu \mathrm{L})$ was then pipetted into a $5 \mathrm{~mm}$ NMR tube prior to NMR analysis.

\subsection{Protein extraction}

Total protein extraction was performed based on Lee and Lo (2008) and Kirkland et al. (2006) with some modifications. Briefly, the gill $(\sim 100 \mathrm{mg}$ ) was homogenized with $1 \mathrm{~mL}$ ice-cold Trizol reagent and centrifuged at $12,000 \times g$ for $5 \mathrm{~min}\left(4^{\circ} \mathrm{C}\right)$ to collect the supernatant. The supernatant was added with $200 \mu \mathrm{L}$ chloroform, and vigorously shook for $3 \mathrm{~min}$ and precipitated for $3 \mathrm{~min}$. Then the mixture was centrifuged at $12,000 \times \mathrm{g}$ for $15 \mathrm{~min}$ at $4{ }^{\circ} \mathrm{C}$ and the upper aqueous layer was discarded. $300 \mu \mathrm{L}$ of absolute ethyl alcohol was added and the mixture was allowed to stand for $3 \mathrm{~min}$ in room temperature before being centrifuged at $2000 \times \mathrm{g}$ for $5 \mathrm{~min}$ at $4{ }^{\circ} \mathrm{C}$. The phenol/ethanol supernatant was precipitated for $30 \mathrm{~min}$ at room temperature by the addition of $750 \mu \mathrm{L}$ isopropanol prior to centrifugation at $14,000 \times g$ for $10 \mathrm{~min}$ at $4{ }^{\circ} \mathrm{C}$. Pellets obtained were washed with $1 \mathrm{~mL}$ ethanol $(95 \%, \mathrm{v} / \mathrm{v})$ and centrifuged at $14,000 \times \mathrm{g}$ for $10 \mathrm{~min}$ at $4{ }^{\circ} \mathrm{C}$. This procedure was repeated twice. The pellets were solubilized in the lysis buffer ( $7 \mathrm{M}$ urea; $2 \mathrm{M}$ thiourea; $4 \%, \mathrm{~m} / \mathrm{v}$ CHAPS; $65 \mathrm{mM}$ DTT and 0.2\%W/V Bio-lyte buffer) and then incubated for $3 \mathrm{~h}$ at room temperature (Tullius et al., 2002). The homogenate was centrifuged at $15,000 \times g$ for $10 \mathrm{~min}$ and the supernatant was applied to electrophoresis. The total concentrations of proteins were determined by Protein Assay Kit of TianGen Corparation.

\subsection{Two-dimensional gel electrophoresis}

The first dimension (IEF) was electrophoresed in a 24-cm Immobiline Drystrip with a nonlinear pH 3-10 gradient. One hundred and forty microgram proteins to a final volume of $450 \mu \mathrm{L}$ were loaded. Isoelectric focusing gel solution contained $7 \mathrm{M}$ urea, $2 \mathrm{M}$ thiourea, 4\%, m/v CHAPS, $65 \mathrm{mM}$ DTT, 0.001\%, m/v Bromophenol blue and $0.2 \%, \mathrm{w} / \mathrm{v}$ Bio-lyte buffer. IEF was conducted at $20^{\circ} \mathrm{C}$ with an Etan IPGphor3 system for a total of $85,858 \mathrm{Vh}$ (Active rehydration was carried out at $30 \mathrm{~V}$ for $12 \mathrm{~h}$, followed by $100 \mathrm{~V}$ for $5 \mathrm{~h}, 500 \mathrm{~V}$ for $1 \mathrm{~h}$, $1000 \mathrm{~V}$ for $1 \mathrm{~h}$, and a linear increase of voltage to $8000 \mathrm{~V}$ for $11 \mathrm{~h}$ ).

After the first dimension, strips were equilibrated in buffer (0.05 M Tris- $\mathrm{HCl}, \mathrm{pH} 8.8 ; 6 \mathrm{M}$ urea; 30\% glycerol; 2\%, w/v SDS; containing $1 \%, \mathrm{w} / \mathrm{v}$ DTT) for $15 \mathrm{~min}$. Subsequently, the strips were incubated for a second $15 \mathrm{~min}$ in the same equilibration buffer with $2.5 \%(\mathrm{w} / \mathrm{v})$ iodoacetamide without DTT (Lee et al., 2006). The second dimension was performed on $12.5 \%$ SDS-PAGE gels using Ettan DALTsix system. After electrophoresis, the gels were silver stained according to the modified protocol from Gharahdaghi et al. (1999) and Mortz et al. (2001). Images were captured by ImageScanner III and spots were quantitatively analyzed by ImageMaster 2D Platinum 7.0. The abundance of each protein spot was estimated by the percentage volume (vol\%). Only those with significant changes $(>1.5$ folds and $p<0.05)$ were considered to be differentially expressed proteins. 


\subsection{In gel digestion and MS analysis}

In gel digestion was performed according to Katayama et al. (2001). The dried samples were resuspended with $5 \mu \mathrm{L} 0.1 \%$ TFA followed by mixing in 1:1 ratio with a saturated solution of $\alpha$-cyano-4-hydroxy-trans-cinnamic acid in $50 \%$ acetonitrile (Shevchenko et al., 1996). One microliter of mixture was analyzed by an ABI 4800 MALDI-TOF/TOF Plus mass spectrometer (Applied Biosystems, Foster City, USA), data were acquired in a positive MS reflector using a CalMix5 standard to calibrate the instrument (ABI4800 Calibration Mixture). Both the MS and MS/MS data were integrated and processed by the GPS Explorer V3.6 software (Applied Biosystems, USA) with default parameters. Proteins were identified based on 95\% or higher confidence interval of their scores in the MASCOT V2.4 search engine (Matrix Science Ltd., London, U.K.). The following parameters were used in the search: NCBInr Metazoa (Animals) (2861494 sequences) database; trypsin as the digestion enzyme; one missed cleavage site; partial modifications of cysteine carbamidomethylation and methionine oxidization; no fixed modifications; $0.15 \mathrm{Da}$ for precursor ion tolerance and $0.25 \mathrm{Da}$ for fragment ion tolerance. Individual ions scores $>40$ indicated identity or extensive homology $(p<0.05)$. For those proteins with multiple identifications by mass spectrometry, the identifications with highest Mascot scores were chosen for further interpretation.

\section{6. ${ }^{1}$ H NMR spectroscopy}

Metabolite extracts of gills from clams were analyzed on a Bruker AV 500 NMR spectrometer at $500.18 \mathrm{MHz}$ (at $298 \mathrm{~K}$ ) as described previously (Liu et al., 2011). All ${ }^{1} \mathrm{H}$ NMR spectra were phased, baseline-corrected, and calibrated (TSP at $0.0 \mathrm{ppm}$ ) using TopSpin (version 2.1, Bruker). Metabolites were assigned and quantified following the tabulated chemical shifts (Fan, 1996) and using the software Chenomx (Evaluation Version, Chenomx Inc., Canada).

\subsection{Antioxidant enzyme activities and lipid peroxidation}

Six gill tissues of $R$. philippinarum from each group were ground in liquid nitrogen, and subjected to antioxidant enzyme activity assays. Measurements of superoxide dismutase (SOD, EC 1.15.1.1), glutathione S-transferases (GST, EC 2.5.1.18), catalase (CAT, EC 1.11.1.6) and glutathione peroxidase (GPx, EC 1.11.1.9) were performed by using commercial enzyme kits (Nanjing Jiancheng Bioengineering Institute, China). Lipid peroxidation was determined by measuring the generation of thiobarbituric acid reactive substances (TBARS) and expressed in terms of malondialdehyde (MDA) content. Protein concentration was determined with Bradford method by using bovine serum albumin as standard (Bradford, 1976). The enzyme activities and MDA content were expressed as $\mathrm{U} \mathrm{mg}^{-1}$ protein and $\mathrm{nmol} \mathrm{mg}^{-1}$ protein, respectively.

\subsection{Determination of total arsenic in gill tissues}

Six gill samples in each group were dried at $80^{\circ} \mathrm{C}$ to constant weights, and then digested in $1 \mathrm{~mL}$ concentrated nitric acid (70\%, Fisher Scientific) using a microwave digestion system (CEM, MAR5). All completely digested samples were diluted with ultrapure water to $5 \mathrm{~mL}$ for the quantification of arsenic. Total arsenic concentrations (National criteria of arsenic for edible marine mollusks: $1 \mu \mathrm{g} / \mathrm{g}$ dry weight) were analyzed using an inductively coupled plasmamass spectrometry (ICP-MS) (Agilent 7500i, Agilent Technologies Co. Ltd., USA). GBW08571 Marine muscle tissue (State Bureau of Technical Supervision, People's Republic of China) was employed as certified reference material for metal analysis to ensure internal quality assurance/quality control (QA/QC) practices (Li et al., 2012).
Table 1

Total arsenic in gills of control and arsenic-exposed clams $(n=6)$ under salinities of 31.1 (normal), 23.3 and 15.6 psu. Data were expressed as mean $\pm \mathrm{SD}\left(\mu \mathrm{gg}^{-1}\right.$ dry weight).

\begin{tabular}{ll}
\hline Exposures & Total arsenic \\
\hline $31.1 \mathrm{psu}$ & $0.35 \pm 0.05$ \\
$23.3 \mathrm{psu}$ & $0.34 \pm 0.05$ \\
$15.6 \mathrm{psu}$ & $0.31 \pm 0.05$ \\
$31.1 \mathrm{psu}+$ As & $0.44 \pm 0.06^{\mathrm{a}}$ \\
$23.3 \mathrm{psu}+$ As & $0.46 \pm 0.04^{\mathrm{a}}$ \\
$15.6 \mathrm{psu}+$ As & $0.51 \pm 0.06^{\mathrm{a}}$ \\
\hline
\end{tabular}

a Statistical significances between combined salinity and arsenic-exposed and corresponding salinity-exposed $R$. philippinarum samples $(p<0.05)$ were determined by one-way ANOVA with Tukey's test.

\subsection{Statistical analysis}

Metabolite concentrations and antioxidant enzyme activities were tested for normal distribution (Ryan-Joiner's test) and homogeneity of variances (Bartlett's test). The effects of salinity, arsenic and their interactions were analyzed using two-way analysis of variance (ANOVA). When interactions between salinity and arsenic were found, the significance of each factor was further analyzed using one-way ANOVA followed by multiple comparisons. A $p$ value less than 0.05 was considered statistically significant. Correlation analysis between the metabolite concentrations was carried out and R-square values are reported. The Minitab software (Version 15 , Minitab Inc., USA) was used for the statistical analysis.

\section{Results and discussion}

\subsection{Accumulation of arsenic in clam gills}

The amounts of total arsenic in gills are presented in Table 1. Significant accumulations $(p<0.05)$ of arsenic were found in clam gills after exposure for $48 \mathrm{~h}$. However, no significant effects were induced by salinities on arsenic accumulation. This work focused mainly on the acute toxicological effects of arsenic in clams. Therefore, only total arsenic contents were measured. However, the significant accumulation of total arsenic could induce potential toxicological effects in clam.

\subsection{Effects of arsenic on antioxidant enzymes and lipid peroxidation in clam gills}

From the analysis of two-way ANOVA (Table 2), CAT activity and MDA content were significantly $(p<0.05)$ affected by arsenic exposure, while SOD, GST and GPX activities were altered by reduced salinities. However, these biochemical indices were not significantly affected by the interaction between salinity and arsenic, which meant that salinity did not influence arsenic-induced oxidative stress. Reduced salinities decreased the activities of SOD, GST and GPx, which meant that hyposaline condition perhaps induced

\section{Table 2}

Two-way analysis of variance (ANOVA) on the biochemical indices including antioxidant enzyme activities (SOD, CAT, GST and GPx) and MDA contents in clam gill tissues. Statistically significant results are indicated in bold.

\begin{tabular}{llll}
\hline Biochemical indices & \multicolumn{2}{l}{$p$ values } & \\
\cline { 2 - 4 } & Salinity & Arsenic & $\begin{array}{l}\text { Salinity } \times \\
\text { Arsenic }\end{array}$ \\
\hline SOD & & 0.396 \\
CAT & $\mathbf{0 . 0 1 2}$ & 0.339 & 0.306 \\
GST & 0.083 & $\mathbf{0 . 0 0 8}$ & 0.428 \\
GPX & $\mathbf{0 . 0 0 6}$ & 0.786 & 0.913 \\
MDA & $\mathbf{0 . 0 1 4}$ & 0.722 & 0.273 \\
\hline
\end{tabular}


Table 3

Biochemical indices in gill tissues $(n=6)$ exposed to various salinities and combined salinity and arsenic $\left(20 \mu g \mathrm{~L}^{-1}\right)$. Values are presented as mean \pm standard deviation.

\begin{tabular}{|c|c|c|c|c|c|c|}
\hline \multirow[t]{2}{*}{ Biochemical indices $^{a}$} & \multicolumn{6}{|l|}{ Exposures } \\
\hline & $31.1 \mathrm{psu}$ & $23.3 \mathrm{psu}$ & $15.6 \mathrm{psu}$ & $31.1 \mathrm{psu}+\mathrm{As}$ & $23.3 \mathrm{psu}+\mathrm{As}$ & $15.6 \mathrm{psu}+\mathrm{As}$ \\
\hline SOD & $31.57 \pm 11.59$ & $17.13 \pm 7.40$ & $23.63 \pm 3.86$ & $28.89 \pm 7.59$ & $22.08 \pm 9.60$ & $29.35 \pm 7.24$ \\
\hline CAT & $81.92 \pm 16.91$ & $62.76 \pm 11.63$ & $71.91 \pm 11.25$ & $86.18 \pm 12.71$ & $82.48 \pm 8.13^{b}$ & $82.37 \pm 10.34$ \\
\hline GST & $274.91 \pm 70.58$ & $212.79 \pm 60.48$ & $223.63 \pm 68.22$ & $313.16 \pm 124.64$ & $172.48 \pm 47.61$ & $205.07 \pm 52.86$ \\
\hline GPx & $164.16 \pm 43.73$ & $122.35 \pm 36.62$ & $140.13 \pm 26.71$ & $175.70 \pm 35.90$ & $124.75 \pm 42.12$ & $139.35 \pm 32.15$ \\
\hline MDA & $18.32 \pm 3.91$ & $19.95 \pm 4.92$ & $17.06 \pm 3.03$ & $22.44 \pm 2.73^{c}$ & $21.68 \pm 4.85$ & $20.15 \pm 2.04$ \\
\hline
\end{tabular}

a The enzyme activities and MDA content were expressed as $\mathrm{U} \mathrm{mg}^{-1}$ protein and $\mathrm{nmol} \mathrm{mg}^{-1}$ protein, respectively.

b Statistical significances between combined salinity and arsenic-exposed and corresponding salinity-exposed $R$. philippinarum samples were less than 0.05 .

c Statistical significances approached $0.05(p<0.1)$.

oxidative stress in clams and resulted in redox balance alterations. Similar results were observed in three marine gastropod species (Deschaseaux et al., 2011). MDA contents were significantly $(p<0.05)$ elevated in arsenic-treated samples (Table 3$)$. It implied that arsenic could induce potential lipid peroxidation in clam gills. The average CAT activity was significantly $(p<0.05)$ increased in clams exposed to arsenic, which meant potential oxidative stress of arsenic. These differential biomarkers of oxidative stress suggested that arsenic with a concentration of $20 \mu \mathrm{g} \mathrm{L}^{-1}$ could induce oxidative stresses in clam gills.

\subsection{Effects of salinity in clam gills at metabolomics and} proteomic levels

\subsubsection{Effects of salinity on the metabolome of clam gills}

A representative ${ }^{1} \mathrm{H}$ NMR spectrum of clam gill extracts was shown in both original and generalized log-transformed forms in Fig. 1. All NMR spectra were dominated by two organic osmolytes, betaine and taurine that were commonly found in marine mollusks (Wu and Wang, 2010).
Two-way ANOVA analysis was conducted on the metabolite concentrations revealing statistical significances of metabolites caused by salinity, arsenic and salinity/arsenic $(p<0.05)$ (Table 4). Obviously, reduced salinities resulted significant changes in most of the detectable metabolites except alanine and histidine (Table 5). The concentrations of amino acids were significantly increased in clam gills with decreased salinities. On the other hand, three organic osmolytes, hypotaurine, betaine and homarine, were significantly $(p<0.001)$ decreased in clam gills under reduced salinities. Low seawater salinities can induce hypo-osmotic stress to marine mollusks. Some marine mollusks can use high intracellular concentrations of free amino acids to balance their intracellular osmolarity with the environment, as reported by Viant et al. (2003). In our case, the concentrations of amino acids were elevated to balance the osmolarity under reduced seawater salinities together with depleted osmolytes, hypotaurine, betaine and homarine. Correlation analysis indicated negative coefficients $\left(R^{2}>0.8\right)$ between hypotaurine and amino acids (valine, isoleucine, leucine, threonine, etc.), with $p$ values less than 0.01 . It confirmed that these amino acids were involved in osmotic regulation in clam. In addition,

Table 4

Two-way analysis of variance (ANOVA) on the metabolite concentrations in clam gill tissues. Statistically significant results are indicated in bold.

\begin{tabular}{|c|c|c|c|c|}
\hline \multirow[t]{2}{*}{ Metabolites } & \multirow[t]{2}{*}{ Chemical shift (ppm, multiplicity) } & \multicolumn{3}{|l|}{$p$ values } \\
\hline & & Salinity & Arsenic & Salinity $\times$ Arsenic \\
\hline \multicolumn{5}{|l|}{ Amino acids } \\
\hline Valine & $1.05(\mathrm{~d})$ & $<0.001$ & 0.002 & $<0.001$ \\
\hline Isoleucine & $1.00(\mathrm{~d})$ & $<0.001$ & $<0.001$ & $<0.001$ \\
\hline Leucine & $0.94(\mathrm{t})$ & $<0.001$ & $<0.001$ & $<0.001$ \\
\hline Threonine & $1.34(\mathrm{~d})$ & $<0.001$ & 0.015 & 0.006 \\
\hline Alanine & $1.48(\mathrm{~d})$ & 0.306 & 0.546 & 0.287 \\
\hline Arginine & $1.70(\mathrm{~m})$ & $<0.001$ & 0.255 & 0.410 \\
\hline Glutamate & $2.05(\mathrm{~m})$ & 0.002 & 0.319 & 0.725 \\
\hline Glutamine & $2.14(\mathrm{~m})$ & $<0.001$ & 0.079 & 0.553 \\
\hline Aspartate & $2.68(\mathrm{ABX})$ & $<0.001$ & 0.269 & 0.512 \\
\hline Lysine & $3.03(\mathrm{t})$ & $<0.001$ & 0.925 & 0.840 \\
\hline Glycine & $3.56(\mathrm{~s})$ & $<0.001$ & 0.286 & 0.749 \\
\hline Tyrosine & $6.91(\mathrm{~d})$ & $<0.001$ & $<0.001$ & $<0.001$ \\
\hline Histidine & $7.12(\mathrm{~s})$ & 0.698 & 0.593 & 0.910 \\
\hline \multicolumn{5}{|l|}{ Organic osmolytes } \\
\hline Hypotaurine & $2.66(t)$ & $<0.001$ & 0.538 & 0.466 \\
\hline Taurine & $3.27(\mathrm{t})$ & $<0.001$ & 0.678 & 0.738 \\
\hline Betaine & $3.91(\mathrm{~s})$ & $<0.001$ & 0.004 & $<0.001$ \\
\hline Homarine & $4.37(\mathrm{~s})$ & $<0.001$ & 0.097 & 0.962 \\
\hline \multicolumn{5}{|l|}{ Phosphagen } \\
\hline Phosphocholine & $3.22(\mathrm{~s})$ & $<0.001$ & 0.348 & 0.733 \\
\hline \multicolumn{5}{|l|}{ Nucleotide } \\
\hline ATP & $6.15(\mathrm{~d})$ & $<0.001$ & 0.041 & 0.038 \\
\hline \multicolumn{5}{|l|}{ Organic acids } \\
\hline Succinate & $2.41(\mathrm{~s})$ & 0.029 & 0.627 & 0.320 \\
\hline Fumarate & $6.52(\mathrm{~s})$ & $<0.001$ & $<0.001$ & $<0.001$ \\
\hline \multicolumn{5}{|l|}{ Carbonhydrate } \\
\hline Glucose & $4.64(\mathrm{~d}), 5.24(\mathrm{~d})$ & $<0.001$ & 0.363 & $<0.001$ \\
\hline \multicolumn{5}{|l|}{ Miscellaneous } \\
\hline Acetoacetate & $2.26(\mathrm{~s})$ & 0.017 & 0.070 & 0.651 \\
\hline Choline & $3.21(\mathrm{~s})$ & 0.009 & 0.624 & 0.310 \\
\hline
\end{tabular}

$\mathrm{s}=$ singlet, $\mathrm{d}=$ doublet, $\mathrm{t}=$ triplet, $\mathrm{m}=$ multiplet, $\mathrm{ABX}=$ complex multiplet involving 2 protons $(\mathrm{A}$ and $\mathrm{B})$ and a heavy atom $(\mathrm{X})$. 
Table 5

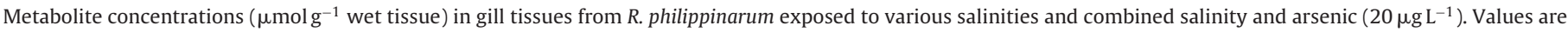
presented as mean \pm standard deviation.

\begin{tabular}{|c|c|c|c|c|c|c|}
\hline \multirow[t]{2}{*}{ Metabolites } & \multicolumn{6}{|l|}{ Exposures } \\
\hline & $31.1 \mathrm{psu}$ & $23.3 \mathrm{psu}$ & $15.6 \mathrm{psu}$ & $31.1 \mathrm{psu}+\mathrm{As}$ & $23.3 \mathrm{psu}+\mathrm{As}$ & $15.6 \mathrm{psu}+$ As \\
\hline Valine & $0.183 \pm 0.042$ & $0.247 \pm 0.071^{\mathrm{a}}$ & $0.376 \pm 0.067^{c}$ & $0.196 \pm 0.052$ & $0.218 \pm 0.063$ & $0.234 \pm 0.074^{\mathrm{f}}$ \\
\hline Isoleucine & $0.119 \pm 0.026$ & $0.167 \pm 0.046^{\mathrm{b}}$ & $0.256 \pm 0.053^{c}$ & $0.139 \pm 0.037$ & $0.137 \pm 0.033$ & $0.155 \pm 0.047^{\mathrm{f}}$ \\
\hline Leucine & $0.171 \pm 0.040$ & $0.235 \pm 0.076^{\mathrm{a}}$ & $0.371 \pm 0.076^{c}$ & $0.176 \pm 0.058$ & $0.208 \pm 0.066$ & $0.193 \pm 0.053^{f}$ \\
\hline Threonine & $0.229 \pm 0.067$ & $0.273 \pm 0.079$ & $0.403 \pm 0.059^{c}$ & $0.257 \pm 0.062$ & $0.228 \pm 0.056$ & $0.289 \pm 0.076^{\mathrm{e}}$ \\
\hline Alanine & $5.364 \pm 1.813$ & $4.608 \pm 1.816$ & $5.684 \pm 1.733$ & $5.640 \pm 1.478$ & $4.775 \pm 1.671$ & $4.465 \pm 1.312$ \\
\hline Arginine & $0.943 \pm 0.341$ & $0.755 \pm 0.141$ & $1.346 \pm 0.262^{\mathrm{b}}$ & $0.786 \pm 0.158$ & $0.799 \pm 0.237$ & $1.240 \pm 0.319$ \\
\hline Glutamate & $4.418 \pm 0.753$ & $4.666 \pm 1.381$ & $5.451 \pm 1.100^{\mathrm{a}}$ & $3.924 \pm 0.215$ & $4.665 \pm 0.928$ & $5.192 \pm 1.018$ \\
\hline Glutamine & $0.435 \pm 0.152$ & $0.517 \pm 0.241$ & $0.827 \pm 0.212^{c}$ & $0.405 \pm 0.146$ & $0.422 \pm 0.158$ & $0.643 \pm 0.355$ \\
\hline Acetoacetate & $0.266 \pm 0.125$ & $0.269 \pm 0.130$ & $0.144 \pm 0.177$ & $0.409 \pm 0.152^{\mathrm{d}}$ & $0.328 \pm 0.138$ & $0.263 \pm 0.151$ \\
\hline Succinate & $0.195 \pm 0.214$ & $0.701 \pm 0.913$ & $1.132 \pm 0.239^{\mathrm{a}}$ & $0.400 \pm 0.235^{\mathrm{d}}$ & $1.168 \pm 1.136$ & $0.768 \pm 0.105^{a}$ \\
\hline Hypotaurine & $2.888 \pm 0.805$ & $1.563 \pm 0.701^{c}$ & $0.817 \pm 0.413^{c}$ & $2.442 \pm 1.195$ & $1.680 \pm 0.672$ & $0.790 \pm 0.356$ \\
\hline Aspartate & $7.847 \pm 1.807$ & $9.682 \pm 2.258$ & $10.986 \pm 3.084^{\mathrm{a}}$ & $7.308 \pm 1.285$ & $8.023 \pm 2.433$ & $11.088 \pm 3.115$ \\
\hline Lysine & $0.264 \pm 0.112$ & $0.427 \pm 0.094^{c}$ & $1.267 \pm 0.436^{c}$ & $0.301 \pm 0.068$ & $0.471 \pm 0.113$ & $1.208 \pm 0.571$ \\
\hline Choline & $0.225 \pm 0.115$ & $0.215 \pm 0.084$ & $0.144 \pm 0.036^{\mathrm{a}}$ & $0.270 \pm 0.138$ & $0.177 \pm 0.069$ & $0.171 \pm 0.050$ \\
\hline Phosphocholine & $0.209 \pm 0.062$ & $0.562 \pm 0.158^{c}$ & $1.348 \pm 0.312^{c}$ & $0.207 \pm 0.048$ & $0.660 \pm 0.093$ & $1.398 \pm 0.316$ \\
\hline Taurine & $68.833 \pm 6.423$ & $75.815 \pm 4.486$ & $73.864 \pm 8.180$ & $66.911 \pm 6.049$ & $75.014 \pm 4.656$ & $74.743 \pm 2.916$ \\
\hline Betaine & $47.704 \pm 3.172$ & $36.169 \pm 2.000^{c}$ & $25.741 \pm 3.673^{c}$ & $45.065 \pm 2.107$ & $40.137 \pm 2.427^{f}$ & $31.132 \pm 3.258^{\mathrm{e}}$ \\
\hline Glycine & $4.701 \pm 1.770$ & $2.779 \pm 0.659^{\mathrm{b}}$ & $2.013 \pm 0.275^{c}$ & $5.327 \pm 1.725$ & $2.801 \pm 0.877$ & $2.429 \pm 0.530$ \\
\hline Glucose & $0.951 \pm 0.626$ & $1.592 \pm 0.633^{\mathrm{a}}$ & $4.100 \pm 1.608^{c}$ & $1.702 \pm 0.515^{\mathrm{e}}$ & $1.827 \pm 0.535$ & $2.493 \pm 0.804^{\mathrm{d}}$ \\
\hline Homarine & $18.162 \pm 4.096$ & $12.469 \pm 4.284^{\mathrm{b}}$ & $7.337 \pm 3.701^{\mathrm{c}}$ & $19.908 \pm 2.830$ & $14.088 \pm 2.856$ & $8.504 \pm 2.675$ \\
\hline ATP & $0.819 \pm 0.111$ & $1.166 \pm 0.084^{c}$ & $1.884 \pm 0.107^{c}$ & $0.803 \pm 0.085$ & $1.181 \pm 0.131$ & $2.468 \pm 0.336^{\mathrm{e}}$ \\
\hline Fumarate & $0.008 \pm 0.005$ & $0.031 \pm 0.008^{c}$ & $0.088 \pm 0.011^{\mathrm{c}}$ & $0.027 \pm 0.006^{\mathrm{f}}$ & $0.025 \pm 0.005$ & $0.054 \pm 0.009$ \\
\hline Tyrosine & $0.118 \pm 0.038$ & $0.167 \pm 0.049^{\mathrm{a}}$ & $0.264 \pm 0.049^{c}$ & $0.128 \pm 0.041$ & $0.142 \pm 0.042$ & $0.128 \pm 0.039^{f}$ \\
\hline Histidine & $0.142 \pm 0.104$ & $0.126 \pm 0.026$ & $0.142 \pm 0.037$ & $0.120 \pm 0.050$ & $0.123 \pm 0.034$ & $0.141 \pm 0.047$ \\
\hline
\end{tabular}

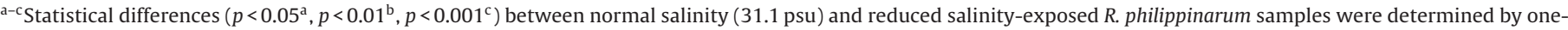
way ANOVA with Tukey's test.

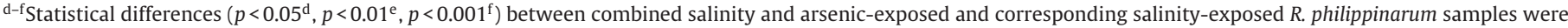
determined by one-way ANOVA with Tukey's test.

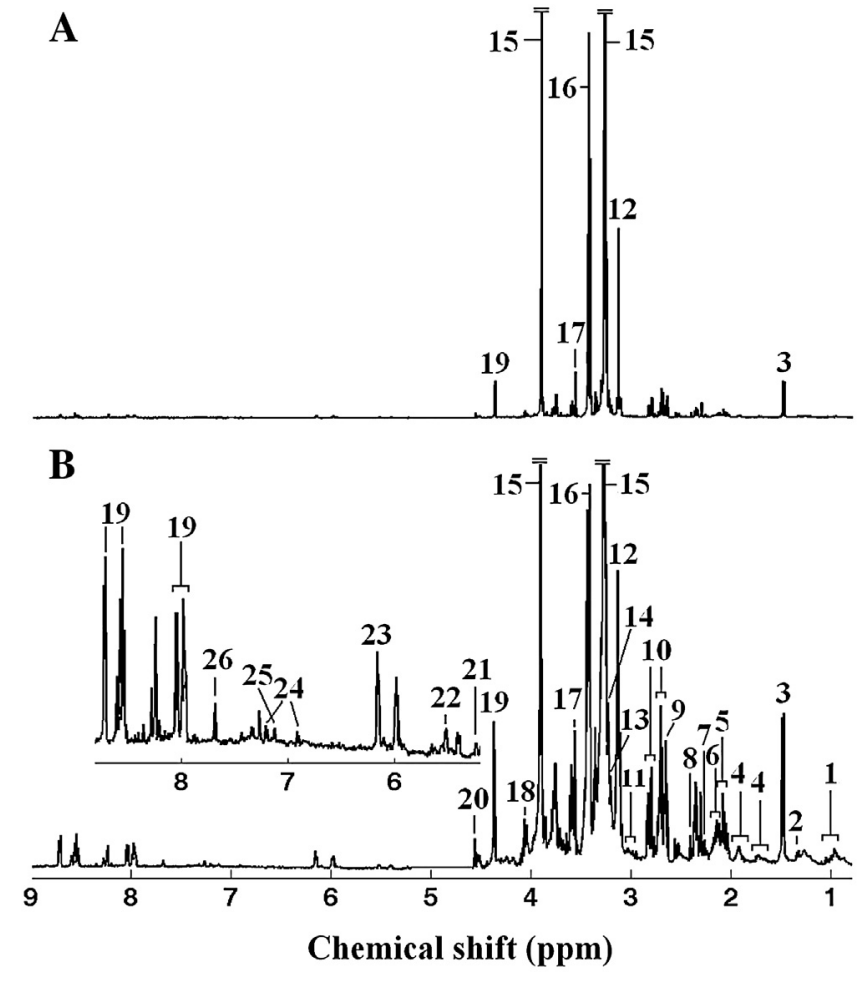

Fig. 1. A representative 1-dimensional $500 \mathrm{MHz}{ }^{1} \mathrm{H}$ NMR spectrum of gill tissue extracts from a White clam of control group in original (A) and generalized log transformed $\left(\lambda=2.0 \times 10^{-9}\right)(B)$ forms. Keys: (1) branched-chain amino acids: isoleucine, leucine and valine, (2) threonine, (3) alanine, (4) arginine, (5) glutamate, (6) glutamine, (7) acetoacetate, (8) succinate, (9) hypotaurine, (10) aspartate, (11) lysine, (12) malonate, (13) choline, (14) phosphocholine, (15) betaine, (16) taurine, (17) glycine, (18) unknown 1 (4.07 ppm), (19) homarine, (20) $\beta$-glucose, (21) $\alpha$-glucose, (22) glycogen, (23) ATP, (24) tyrosine, (25) histidine and (26) unknown 2 (7.68 ppm). glucose, fumarate and ATP was significantly $(p<0.05)$ increased. Glucose is an energy storage compound and fumarate is an intermediate in Krebs cycle used by cells to produce energy in the form of ATP from food. Since hypoosmotic stress can significantly reduce the food intake, the experimental clams under low salinities were believed to be under restriction of food during exposure. In abalone (Haliotis rufescens), the levels of amino acids and glucose were decreased in muscle, digestive gland and hemolymph during starvation (Viant et al., 2003). In our case, the contrary results were found in clam gills, therefore it is speculated that increased glucose, fumarate and ATP could indicate that clam consumed higher amounts of energy related metabolites in digestive gland, and therefore more glucose, fumarate and ATP were biosynthesized in gills to maintain energy metabolism in clam.

\subsubsection{Effects of salinity on the proteome of clam gills}

The representative 2-DE gels of arsenic-blank and arsenictreated clam samples under three salinities are shown in Fig. 2. To discover protein biomarkers of hypo-osmotic stress induced by reduced salinities, we compared the 2-DE gels from clam gills under normal (31.1 psu) and reduced salinities (23.3 and $15.6 \mathrm{psu}$ ). A total of fifteen protein spots under reduced salinities were significantly altered in abundance $(>1.5$ folds; $p<0.05)$, and ten of them were identified by MALDI-TOF-MS/MS (Table 6). These proteins were found to be involved in cytoskeleton organization (3 proteins), defensive system (5 proteins), signal transduction ( 1 protein) and metabolism (1 protein). Actin is an abundant cytoskeletal protein that is a component of microfilaments in cells. In the clam gills under low salinity (15.6 psu), one cytoskeletal actin was down-regulated. However, another cytoplasmic actin was up-regulated in clam gills under medium salinity (23.3 psu). The alteration in actins has been reported in response to cellular stress or apoptosis, such as M. galloprovincialis exposed to cylindrospermopsin produced by Cylindrospermopsis raciborskii (Puerto et al., 2011). In our case, the alteration in actins implied 

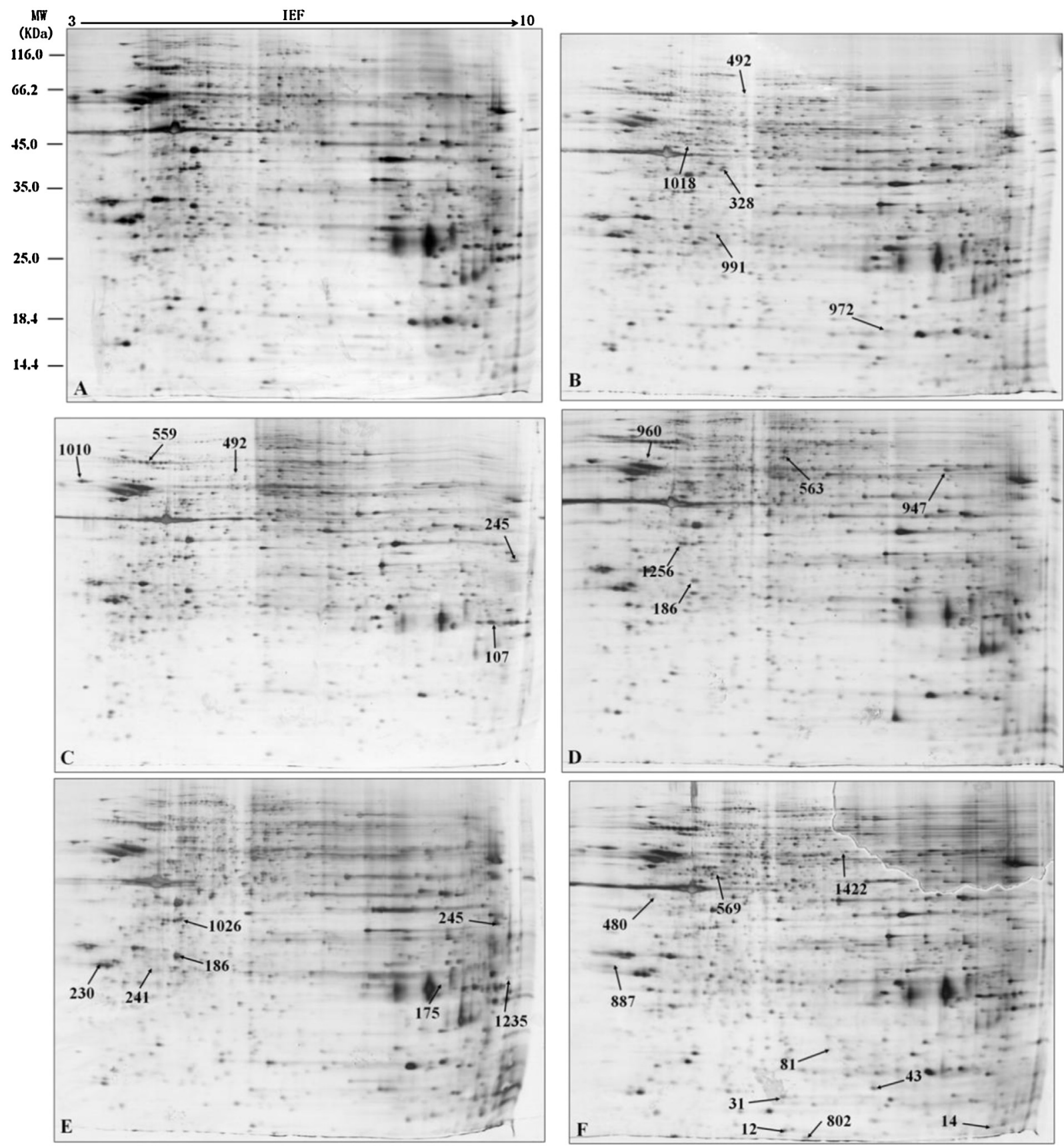

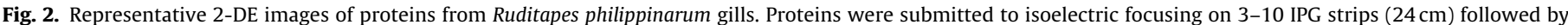

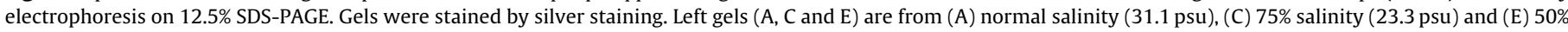

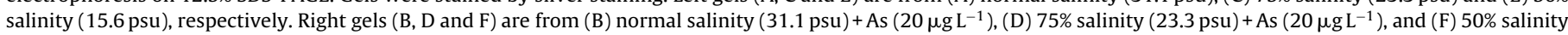
$(15.6 \mathrm{psu})+\mathrm{As}\left(20 \mu \mathrm{g} \mathrm{L}^{-1}\right)$, respectively. The proteins spots observed in all three biological replicates were analyzed by MALDI-TOF/TOF mass spectrometry.

that reduced salinities perhaps caused cellular injury due to cytoskeletal disruption under hypo-osmotic status, which was further confirmed by down-regulated tubulin. Two small heat shock proteins (sHSP) were significantly down-regulated in the reducedsalinity exposed groups, respectively. Outer dense fiber protein (ODFP) was suggested as the 10th member of the superfamily of mammalian sHSPs (Fontaine et al., 2003). In this study, one ODFP-like protein was also found to be down-regulated in lowsalinity exposed groups. sHSPs usually execute two main defensive functions including cytoskeleton stabilization and anti-apoptotic activity (Boncoraglioa et al., 2012). Hereby, the down-regulation of these sHSPs indicated potential cellular injury and (or) apoptosis caused by reduced salinities, which was confirmed by altered actin and tubulin expression. Annexin-1 is a calcium-dependent phospholipid binding protein that participates in the mediation of apoptosis (Gerke and Moss, 2002). The significant down-regulation of annexin-1 in medium-salinity exposed group perhaps indicated potential apoptosis caused by hypo-osmotic stress. The 14-3-3 proteins have the ability to bind diverse signaling proteins (kinases, phosphatases, transmembrane receptors and the phosphorylated Bad proteins) and so prevent apoptosis (Muslin et al., 1996). One 14-3-3 protein was apparently down-regulated 
Table 6

List of protein spots differentially expressed in Ruditapes philippinarum gills under salinity and As treatment.

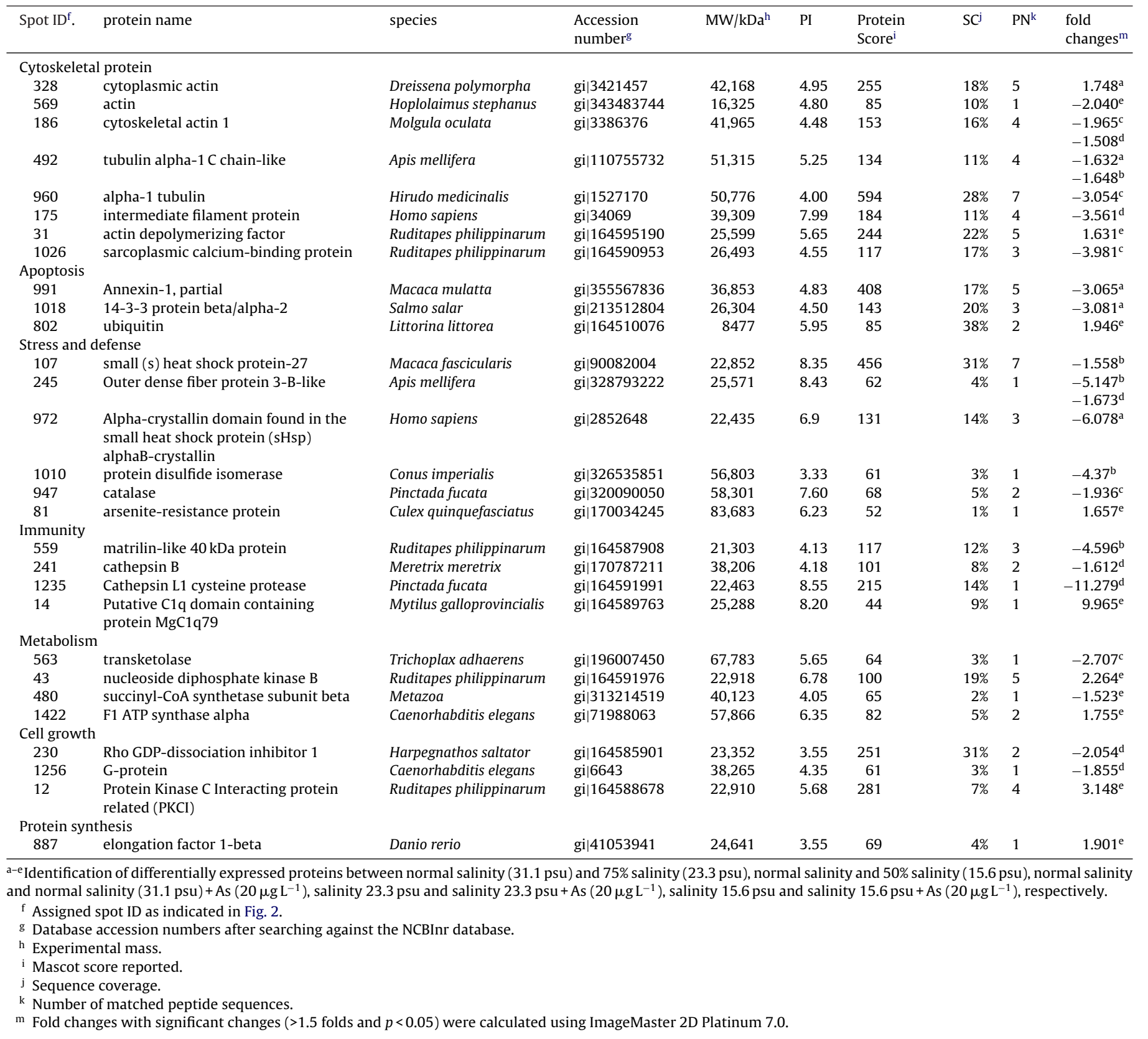

( $>3$ folds) in clam gills under medium salinity (23.3 psu), further indicating that this salinity induced apoptosis as well. Matrilin is a subfamily of extracellular matrix proteins that are involved in immune defense (Bouchut et al., 2006). A down-regulated matrilinlike $40 \mathrm{kDa}$ protein implied that the low salinity could induce immune responses in clams. Protein disulfide isomerase (PDI) is a metabolic enzyme catalyzing the formation and breakage of disulfide bonds between sulfides ( $\mathrm{S}-$ ) in cysteine residues of folding proteins. As a member of the superfamily of thioredoxin, PDI has been found in response to oxidative stress (Freedman et al., 1994). The down-regulation of PDI could imply that the low salinity (15.6 psu) affected the antioxidant system in clam gills.

\subsection{Effects of arsenic in clam gills under various salinities at} metabolomics and proteomic levels

\subsubsection{Effects of arsenic on the metabolome of clam gills under various salinities}

From the analysis of two-way ANOVA, the metabolites including valine, leucine, isoleucine, threonine, tyrosine, betaine, fumarate, acetoacetate and ATP were significantly affected by both arsenic and interaction between arsenic and salinity (Table 5). Clearly, these metabolic biomarkers demonstrated that reduced salinities influenced arsenic-induced effects in clam. To further the comparison, one-way ANOVA analysis was conducted on these metabolite concentrations from both arsenic-treated and 
arsenic-blank clam samples (Table 6). Arsenic exposure increased the levels of succinate and fumarate in clam gills under normal salinity (31.1 psu), which suggested that arsenic caused disturbance in energy metabolism. Under reduced salinities (23.3 and $15.6 \mathrm{psu}$ ), betaine was significantly elevated in clam gills exposed to arsenic compared to the samples from arsenic-blank group, suggesting arsenic-induced osmotic stress in clam gills. However, significant decreases of amino acids (valine, leucine, isoleucine, threonine and tyrosine) were observed together with increases of ATP and betaine in clam gills under low salinity (15.6 psu). The oxidizable amino acids could be involved in cellular energy metabolism in marine mollusks, which was observed in abalone (H. rufescens) (Viant et al., 2003).

\subsubsection{Effects of arsenic on the proteome of clam gills under various salinities}

Comparisons between arsenic-blank and arsenic-exposed groups under each salinity were conducted to characterize the differential proteomic responses. Overall, twenty-five protein spots were significantly altered in arsenic-exposed clam samples, and twenty-one proteins were identified by MALDI-TOF-MS/MS analysis (Table 6). Obviously, the responsive proteins in arsenic-exposed groups under each salinity were different, which demonstrated that reduced salinities influenced the toxicological effects of arsenic as indicated by metabolomics. Under normal salinity, cytoskeletal actin 1 and alpha- 1 tubulin were down-regulated in arsenicexposed clam gills, implying cellular injury caused by arsenic. One catalase (CAT) that is related to anti-oxidative stress was down-regulated as well. However, the total CAT activity was not significantly changed (Table 4). The lack of correlation between certain protein and enzyme activity is not surprising, since enzyme measurements include all CAT members of this family. Transketolase is an important enzyme in pentose phosphate pathway (PPP) that is responsible for energy transduction and nucleic acid synthesis (Klinga et al., 2008). The down-regulation of transketolase could imply the inhibition of pentose phosphate pathway. It is reported that oxidative stress can inhibit the PPP, which was observed in zebrafish liver exposed to brominated flame retardants (Klinga et al., 2008). In this work, arsenic exposure induced oxidative stress in clam gills under normal salinity (31.1 psu), which perhaps caused the down-regulation of transketolase. Sarcoplasmic calcium-binding proteins (SCPs) are an important $\mathrm{Ca}^{2+}$-binding system in the maintenance of intracellular $\mathrm{Ca}^{2+}$ homeostasis (Gao et al., 2006). Therefore, the down-regulated SCP might mean the dysregulation of cellular $\mathrm{Ca}^{2+}$ homeostasis.

In the clam gills under medium salinity (23.3 psu), one cytoskeletal actin was down-regulated, which was similar to that under normal salinity. In invertebrate, cathepsin B contributed to the digestion of blood protein and suggested that it might play a role in crustacean innate immunity, which were observed in cadmium-exposed European bullhead Cottus gobio (Dorts et al., 2011). Additionally, cathepsin L1 cysteine protease is involved in immune responses as well (Dorts et al., 2011). In this study, the dramatic down-regulation of cathepsin L1 (>11 fold) and cathepsin $B$ suggested that arsenic exposure could affect the immune systems in clam gills under medium salinity. As the constituents of deformable cellular latticework, down-regulated intermediate filament proteins (IFP) demonstrated the cellular injury by arsenic in clam gills combined with one altered ODFP. G proteins play important roles in growth-regulating signal pathways, while Rho GDP dissociation inhibitors (RhoGDIs) are the regulators of Rho GTPases and involved in normal cell growth as well (Neer, 1995; Davis et al., 2000). Both down-regulated G protein and RhoGDI indicated that arsenic influenced normal cell growth in clam gills under medium salinity.
Protein kinase $\mathrm{C}$ interacting protein I ( $\mathrm{PKCI}$ ) has been reported as an interacting partner for regulators of $G$ protein signaling (RGS) that plays essential roles in normal cell growth (Ajit et al., 2007). However, no $G$ protein alternation was observed in clam gills under low salinity (15.6 psu). The significant up-regulation of PKCI might be related to the disorder of normal cell growth caused by arsenic exposure.

C1q domain containing protein is reported to function as a pattern recognition receptor (PRR) in mollusk innate immunity (Zhang et al., 2008). Under low salinity (15.6 psu), one C1q domain containing protein was the most remarkably up-regulated protein, which suggested the disturbance in immune system of arsenicexposed clam. Actin-depolymerizing factor (ADF) is one of the actin cytoskeleton-modulating proteins. The accumulation of ADF can lead to depolymerization of actin filaments, indicating cellular injury in clam gills combined with the altered actin.

Ubiquitin is a small regulatory protein involved in the nonlysosomal degradation of intracellular proteins (Kimura and Tanaka, 2010). The up-regulation of ubiquitin supports the hypothesis that arsenic exposure could potentially result in apoptosis under low salinity. Notably, one arsenite-resistance protein was found in clam gills exposed to arsenic $(\mathrm{As}(\mathrm{V}))$ at low salinity. Although arsenic biotransformation has been reported in marine animals (Whaley-Martin et al., 2012), however, no information of arseniteresistance mechanisms in $R$. philippinarum is available so far. One recent work reported that blue mussels (M. edulis) from Seal Harbor (Guysborough County, Nova Scotia, Canada) with high arsenic concentrations (30-200 $\mathrm{g} \mathrm{L}^{-1}$ seawater) possessed $\mathrm{As}(\mathrm{III})$ with proportions ranging from $16 \%$ to $36 \%$ of total arsenic (WhaleyMartin et al., 2012). It indicated that marine mollusks have potential capabilities to transform arsenate into arsenite. In our case, especially, low salinity could lead to more efficient biotransformation of arsenate into arsenite in clam $R$. philippinarum. Therefore, the arsenite resistance protein was up-regulated to detoxify arsenite.

Nucleoside diphosphate kinases (NDPKs) are enzymes that catalyze the exchange of phosphate groups between various nucleoside diphosphates. For example, NDPKs can convert guanosine triphosphate (GTP) to ATP in Krebs cycle. F-ATP synthase is responsible for the production of ATP for energy supply in the mitochondria (Leyva et al., 2003). Obviously, the up-regulation of NDPK and ATP synthase in clam gills under low salinity demonstrated the alterations in energy metabolisms, especially in Krebs cycle caused by arsenic exposure. It was also confirmed by the down-regulated succinyl-CoA synthetase (SCS) that is another enzyme catalyzing succinyl CoA to succinate in Krebs cycle. As the results, two metabolites, succinate and ATP involved in the metabolic pathways catalyzed by succinyl-CoA synthetase and ATP synthase were correspondingly down-regulated and up-regulated, respectively (Table 6, Fig. 3 ). These findings evidently revealed that a combination of metabolomics and proteomics was robust to elucidate the toxicological effects of environmental pollutants.

In conclusion, a combined metabolomic and proteomic approach was used to investigate the toxicological effects of the environmentally relevant arsenic exposure on gills of $R$. philippinarum under different salinities. Overall, arsenic with a concentration of $20 \mu \mathrm{g} \mathrm{L}^{-1}$ induced osmotic stress and cellular injury, and affected signal transduction and immune system in clam $R$. philippinarum. Both metabolomic and proteomic responses indicated that that reduced salinities mainly influenced the stress response pathways and in part energy metabolism induced by $20 \mu \mathrm{g} \mathrm{L}^{-1}$ arsenic. In addition, some proteomic biomarkers involved in energy metabolism were confirmed by metabolomic biomarkers. These findings demonstrated the complementary usefulness of metabolomics and proteomics in elucidating toxicological effects of environmental pollutants. 


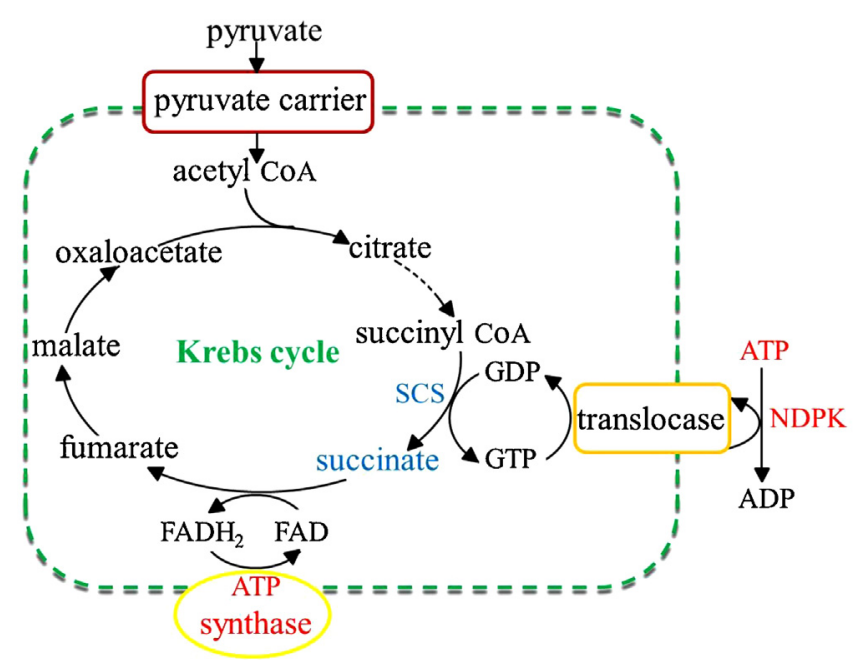

Fig. 3. A schematic presentation of pathways indicated by altered metabolites and proteins. The identified metabolites and proteins were involved in energy metabolism and marked in red (increased) and blue (decreased). (For interpretation of the references to color in this figure legend, the reader is referred to the web version of this article.)

\section{Acknowledgement}

This research was supported by NSFC (41106102 and 21237004).

\section{References}

Agency for Toxic Substances and Disease Registry (ATSDR). Toxicological profile for arsenic. Public Health Service, US Department of Health and Human Services, Atlanta, GA, USA, 2007

Ahsan, N., Renaut, J., Komatsu, S., 2009. Recent developments in the application of proteomics to the analysis of plant responses to heavy metals. Proteomics 9, 2602-2621.

Ajit, S.K., Ramineni, S., Edris, W., Hunt, R.A., Hum, W.T., Hepler, J.R., Young, K.H., 2007. RGSZ1 interacts with protein kinase $C$ interacting protein $\mathrm{PKCI}-1$ and modulates mu opioid receptor signaling. Cellular Signalling 19, 723-730.

Baig, J.A., Kazi, T.G., 2012. Translocation of arsenic contents in vegetables from growing media of contaminated areas. Ecotoxicology and Environment Safety 75, 27-32.

Boncoraglioa, A., Minoiaa, M., Carra, S., 2012. The family of mammalian small heat shock proteins (HSPBs): implications in protein deposit diseases and motor neuropathies. International Journal of Biochemistry and Cell Biology 44, 1657-1669.

Bouchut, A., Roger, E., Coustau, C., Gourbal, B., Mitta, G., 2006. Compatibility in the Biomphalaria glabrata/Echinostoma caproni model: potential involvement of adhesion genes. International Journal for Parasitology 36, 175-184.

Bradford, M., 1976. A rapid and sensitive method for the quantification of microgram quantities of protein utilizing the principle of protein-dye binding. Analytical Biochemistry 72, 248-254.

Bulletins of Chinese Marine Environment Quality (BCMEQ). State Oceanic Administration, P.R. China, 2007-2010.

Choi, J.-W., Liu, H., Song, H., Park, J.H.Y., Yun, J.W., 2012. Plasma marker proteins associated with the progression of lung cancer in obese mice fed a high-fat diet. Proteomics 12, 1999-2013.

Clowes, L.A., Francesconi, K.A., 2004. Uptake and elimination of arsenobetaine by the mussel Mytilus edulis is related to salinity. Comparative Biochemistry and Physiology. C: Comparative Pharmacology 137, 35-42.

Davis, A.R., Clements, M.K., Bunger, P.L., Siemsen, D.W., Quinn, M.T., 2000. Cloning and characterization of bovine low molecular weight GTPases (Rac1 and Rac2) and Rho GDP-dissociation Inhibitor 2 (D4-GDI). Veterinary Immunology and Immunopathology 74, 285-301.

Davis, B., 2005. Growing pains for metabolomics. The Scientist 19, 25-28.

Deschaseaux, E., Taylor, A., Maher, W., 2011. Measure of stress response induced by temperature and salinity changes on hatched larvae of three marine gastropod species. Journal of Experimental Marine Biology and Ecology 397, 121-128.

Dorts, J., Kestemont, P., Dieu, M., Raes, M., Silvestre, F., 2011. Proteomic response to sublethal cadmium exposure in a sentinel fish species Cottus gobio. Journal of Proteome Research 10, 470-478.

Fan, W.M.T., 1996. Metabolite profiling by one- and two-dimensional NMR analysis of complex mixtures. Progress in Nuclear Magnetic Resonance Spectroscopy 28, $161-219$.
Fedorenkova, A., Vonk, J.A., Lenders, H.J.R., Ouborg, N.J., Breure, A.M., Hendriks, A.J., 2010. Ecotoxicogenomics: bridging the gap between genes and populations. Environmental Science and Technology 44, 4328-4333.

Fontaine, J.M., Rest, J.S., Welsh, M.J., Benndorf, R., 2003. The sperm outer dense fiber protein is the $10^{\text {th }}$ member of the superfamily of mammalian small stress proteins. Cell Stress and Chaperones 8, 62-69.

Freedman, R.B., Hirst, T.R., Tuite, M.F., 1994. Protein disulphide isomerase: building bridges in protein folding. Trends in Biochemical Sciences 19, 331-336.

Gao, Y., Gillen, C.M., Wheatly, M.G., 2006. Molecular characterization of the sarcoplasmic calcium-binding protein (SCP) from crayfish Procambarus clarkia Comparative Biochemistry and Physiology. B: Comparative Biochemistry 144, 478-487.

Gerke, V., Moss, S.E., 2002. Annexins: from structure to function. Physiological Reviews 82, 331-371.

Gharahdaghi, F., Weinberg, C.R., Meagher, D.A., Mische, S.M., 1999. Mass spectrometric identification of proteins from silver-stained polyacrylamide gel: a method for the removal of silver ions to enhance sensitivity. Electrophoresis 20, 601-605.

Harrington, C.F., Ojo, A.A., Lai, V.W.M., Reimer, K.J., Cullen, W.R., 1997. The identification of some water-soluble arsenic species in the marine brown algae Fucus distichus. Applied Organometallic Chemistry 11, 931-940.

Hines, A., Oladiran, G.S., Bignell, J.P., Stentiford, G.D., Viant, M.R., 2007. Direct sampling of organisms from the field and knowledge of their phenotype: key recommendations for environmental metabolomics. Environmental Science and Technology 41, 3375-3381.

Katayama, H., Nagasu, T., Oda, Y., 2001. Improvement of in-gel digestion protocol for peptide mass fingerprinting by matrix-assisted laser desorption/ionization time-of-flight mass spectrometry. Rapid Communications in Mass Spectrometry $15,1416-1421$.

Kimura, Y., Tanaka, K., 2010. Regulatory mechanisms involved in the control of ubiquitin homeostasis. Journal of Biochemistry 147, 793-798.

Kirkland, P.A., Busby Jr., J., Stevens Jr., S., Maupin-Furlow, J.A., 2006. Trizol-based method for sample preparation and isoelectric focusing of halophilic proteins. Analytical Biochemistry 351, 254-259.

Klinga, P., Norman, A., Andersson, P.L., Norrgren, L., Forlin, L., 2008. Gender-specific proteomic responses in zebrafish liver following exposure to a selected mixture of brominated flame retardants. Ecotoxicology and Environment Safety 71, 319-327.

Laing, I., Child, A.R., 1996. Comparative tolerance of small juvenile palourdes (Tapes decussates L.) and Manila clams (Tapes philippinarum Adams \& Reeve) to low temperature. Journal of Experimental Marine Biology and Ecology 195, 267-285.

Lee, F.W.-F., Lo, S.C.-L., 2008. The use of Trizol reagent (phenol/guanidine isothiocyanate) for producing high quality two-dimensional gel electrophoretograms (2-DE) of dinoflagellates. Journal of Microbiological Methods 73, 26-32.

Lee, S.C., Chan, J., Clement, M.V., Pervaiz, S., 2006. Functional proteomics of resveratrol-induced colon cancer cell apoptosis: caspase-6-mediated cleavage of lamin A is a major signaling loop. Proteomics 6, 2386-2394.

Leyva, J.A., Bianchet, M.A., Amzel, L.M., 2003. Understanding ATP synthesis: structure and mechanism of the F1-ATPase (review). Molecular Membrane Biology 20, 27-33.

Li, L., Liu, X., You, L., Zhang, L., Zhao, J., Wu, H., 2012. Uptake pathways and subcellular fractionation of Cd in the polychaete Nereis diversicolor. Ecotoxicology 21, 104-110.

Liao, C.M., Chen, B.C., Singh, S., Lin, M.C., Liu, C.W., Han, B.C., 2003. Acute toxicity and bioaccumulation of arsenic in tilapia (Oreochromis mossambicus) from a blackfoot disease area in Taiwan. Environmental Toxicology 18, 252-259.

Lin, C.Y., Wu, H., Tjeerdema, R.S., Viant, M.R., 2007. Evaluation of metabolite extraction strategies from tissue samples using NMR metabolomics. Metabolomics 3, 55-67.

Lindon, J.C., Nicholson, J.K., Everett, J.R., 1999. NMR spectroscopy of biofluid. Annual Reports on Nuclear Magnetic Resonance Spectroscopy 38, 1-88.

Liu, X., Zhang, L., You, L., Yu, J., Zhao, J., Li, L., Wang, Q., Li, F., Liu, D., Wu, H., 2011. Differential toxicological effects induced by mercury in gills from three pedigrees of Manila clam Ruditapes philippinarum by NMR-based metabolomics. Ecotoxicology 20, 177-186.

Meng, W., Liu, Z., Fan, W., 2004. Study on pollutant characters of main estuary of the Bohai Bay. Research of Environmental Sciences 17, 66-69 (in Chinese).

Moraga, D., Mdelgi-Lasram, E., Romdhane, M.S., El Abed, A., Boutet, I., Tanguy, A., Auffret, M., 2002. Genetic responses to metal contamination in two clams: Ruditapes decussatus and Ruditapes philippinarum. Marine Environment Research 54, 521-525.

Mortz, E., Krogh, T.N., Vorum, H., Gorg, A., 2001. Improved silver staining protocols for high sensitivity protein identification using matrix-assisted laser desorption/ionization-time of flight analysis. Proteomics 1, 1359-1363.

Muslin, A.J., Tanner, J.W., Allen, P.M., Shaw, A.S., 1996. Interaction of 14-3-3 with signaling proteins is mediated by the recognition of phosphoserine. Cell 84, 889-897.

Neer, E.J., 1995. Heterotrimeric G proteins: organizers of transmembranesignals. Cell 80, 249-257.

Neff, J.M., 1997. Ecotoxicology of arsenic in the marine environment. Environmental Toxicology and Chemistry 16, 917-927.

Pedras, M.S.C., Zheng, Q.A., 2010. Metabolic responses of Thellungiella halophila/salsuginea to biotic and abiotic stresses: metabolite profiles and quantitative analyses. Phytochemistry 71, 581-589.

Poynton, H.C., Taylor, N.S., Hicks, J., Colson, K., Chan, S., Clark, C., Scanlan, L., Loguinov, A.V., Vulpe, C., Viant, M.R., 2011. Metabolomics of microliter hemolymph 
samples enables an improved understanding of the combined metabolic and transcriptional responses of Daphnia magna to cadmium. Environmental Science and Technology 45, 3710-3717.

Puerto, M., Campos, A., Prieto, A., Cameán, A., de Almeida, A.M., Coelho, A.V., Vasconcelos, V., 2011. Differential protein expression in two bivalve species: Mytilus galloprovincialis and Corbicula fluminea: exposed to Cylindrospermopsis raciborskii cells. Aquatic Toxicology 101, 109-116.

Santos, E.M., Ball, J.S., Williams, T.D., Wu, H., Ortega, F., van Aerle, R., Katsiadaki, I., Falciani, F., Viant, M.R., Chipman, J.K., Tyler, C.R., 2010. Identifying health impacts of exposure to copper using transcriptomics and metabolomics in a fish model. Environmental Science and Technology 44, 820-826.

Shevchenko, A., Wilm, M., Vorm, O., Mann, M., 1996. Mass spectrometric sequencing of proteins from silver-stained polyacrylamide gels. Analytical Chemistry 68, $850-858$.

Suhendrayatna, O., Nakajima, T., Maeda, S., 2002. Studies on the accumulation and transformation of arsenic in freshwater organisms I: accumulation, transformation and toxicity of arsenic compounds on the Japanese Medaka, Oryzias latipes. Chemosphere 46, 319-324.

Tullius, M.V., Phillips, N.J., Scheffler, N.K., Samuels, N.M., Munson Jr., R.S., Hansen, E.J., Stevens-Riley, M., Campagnari, A.A., Gibson, B.W., 2002. The lbgAB gene cluster

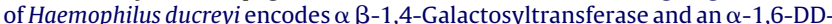
heptosyltransferase involved in lipooligosaccharide biosynthesis. Infection and Immunity 70, 2853-2861.

Ventura-Lima, J., Bogo, M.R., Monserrat, J.M., 2011. Arsenic toxicity in mammals and aquatic animals: a comparative biochemical approach. Ecotoxicology and Environment Safety 74, 211-218.

Viant, M.R., Rosenblum, E.S., Tjeerdema, R.S., 2003. NMR-based metabolomics: a powerful approach for characterizing the effects of environmental stressors on organism health. Environmental Science and Technology 37, 4982-4989.

Whaley-Martin, K.J., Koch, I., Moriarty, M., Reimer, K.J., 2012. Arsenic speciation in blue mussels (Mytilus edulis) along a highly contaminated arsenic gradient. Environmental Science and Technology 46, 3110-3118.
Wu, H., Southam, A.D., Hines, A., Viant, M.R., 2008. High throughput tissue extraction protocol for NMR and Mass spectrometry based metabolomics. Analytical Biochemistry 372, 204-212.

Wu, H., Wang, W.X., 2010. NMR-based metabolomic studies on the toxicological effects of cadmium and copper on green mussels Perna viridis. Aquatic Toxicology 100, 339-345.

Wu, H., Zhang, X., Li, X., Li, Z., Wu, Y., Pei, F., 2005. Comparison of metabolic profiles from serum from hepatotoxin-treated rats by nuclear-magneticresonance-spectroscopy-based metabonomic analysis. Analytical Biochemistry 340, 99-105.

Zhang, G., Liu, D., Wu, H., Chen, L., Han, Q., 2012a. Heavy metal contamination in the marine organisms in Yantai coast, northern Yellow Sea of China. Ecotoxicology 21, 1726-1733.

Zhang, H., Ding, L., Fang, X., Shi, Z., Zhang, Y., Chen, H., Yan, X., Dai, J., 2011a. Biological responses to perfluorododecanoic acid exposure in rat kidneys as determined by integrated proteomic and metabonomic studies. PLoS ONE 6, e20862.

Zhang, H., Song, L., Li, C., Zhao, J., Wang, H., Qiu, L, Ni, D., Zhang, Y., 2008. A novel C1q-domain-containing protein from Zhikong scallop Chlamys farreri with lipopolysaccharide binding activity. Fish and Shellfish Immunology 25 281-289.

Zhang, W., Huang, L., Wang, W.-X., 2011b. Arsenic bioaccumulation in a marine juvenile fish Terapon jarbua. Aquatic Toxicology 105, 582-588.

Zhang, W., Liu, Y., Zhang, H., Dai, J., 2012b. Proteomic analysis of male zebrafish livers chronically exposed to perfluorononanoic acid. Environment International 42 20-30.

Zhang, X., 2001. Investigation of pollution of $\mathrm{Pb}, \mathrm{Cd}, \mathrm{Hg}$, As in sea water and deposit of the Bohai Sea area. Heilongjiang Environmental Journal 25, 87-90 (in Chinese).

Zhou, H., Greig, A., You, C.F., Lai, H., Tang, J., Guan, Y., Yuan, D., 2011. Arsenic in a speleothem from central China: stadial-interstadial variations and implications. Environmental Science and Technology 45, 1278-1283. 